\title{
A Brief Analysis of the Core of Comprehensive and Strict Party Management in the New Era
}

\author{
Xiaoyun Jiao* Qianqian Wang \\ School of Marxism, Hunan Normal University, Yuelu District, Changsha Hunan, China \\ *Corresponding author: Xiaoyun Jiao.Email:jiaoxiaoyun2008@vip.qq.com
}

\begin{abstract}
The Report of the 19th National Congress puts forward the general requirements of strengthening the Party's construction in the new era. Moreover, it plans the general layout of the Party's construction in the new era, drawing a new blueprint for the Party's construction in the new era. Planning the general layout of party building in the new era, it draws a new blueprint for party building in the new era, sketching a map and timetable for the new magnificent project of comprehensively promoting party building in the new era. To promote the comprehensive and strict administration of the Party in the new era, it is necessary to identify the key points, including giving full play to the leading role of the Party's political construction, strengthening the party's long-term ruling ability, and mobilizing the enthusiasm, initiative and creativity of the whole Party.
\end{abstract}

Keywords: The new era, Comprehensive and strict party, Core

\section{INTRODUCTION}

As the leading core of socialism with Chinese characteristics, the CPC's self-construction is the objective requirement and political guarantee for the sustainable development of the Chinese nation. In order to push forward the modernization drive in the new era and successfully fulfill the two-hundred-year goal, it is imperative to uphold the Party's leadership in all work. To uphold the Party's leadership, we must reinforce the Party's leadership and constantly enhance the Party's long-term ruling ability. Facing the complicated situation at home and abroad, with various challenges inside and outside the Party, the Communist Party can win great victories of socialism with Chinese characteristics in the new era only by constantly strengthening its own construction and persisting in self-innovation and self-revolution. Therefore, the report of the 19th National Congress puts forward the general requirements for strengthening the Party's construction in the new era, laying out a map and a timetable for the new great project of comprehensively promoting the Party's construction in the new era. Party building is an all-round and complex systematic project that needs to be comprehensively promoted, with emphasis, multiparty linkage, unique features, long-term adherence and short-term goals. To promote the and strict administration of the party in the new era, it is pivotal to grasp the main contradictions and identify the key points among the myriad problems. comprehensive.

\section{GIVE FULL PLAY TO THE LEADING ROLE OF THE PARTY'S POLITICAL CONSTRUCTION}

\subsection{Firmly uphold two maintenances}

Centralized and unified leadership of the CPC Central Committee is the highest principle of the Party's leadership. Strengthening and maintaining the centralized and unified leadership of the CPC Central Committee is the common political responsibility of the whole party. For a party with more than 89 million party members and more than 4.4 million grass-roots party organizations, the entire party would become fragmented and difficult to form a strong cohesive force and combat effectiveness without a strong core of leadership. Above all, it is momentous to maintain the core position of General Secretary $\mathrm{Xi}$ Jinping. It is because the establishment of Comrade Xi Jinping as the core of the whole Party is determined by the serious and complicated situation of struggle. Adhering to the authority of the CPC Central Committee and centralizing and unifying leadership is fundamentally consistent with maintaining the core position of General Secretary $\mathrm{Xi}$ Jinping. All comrades in the party, especially leading cadres, should keep a clear political 
mind, be loyal to the party with a high degree of political consciousness and sense of alignment, and consciously align with General Secretary Xi Jinping. Secondly, it's vital to adhere to the four obediences and enhance the four consciousnesses. Four obediences is the basic principle of inner-party democracy. The most fundamental and core of adhering to the four obedience is to insist that the whole party obey the central government, which is the fundamental element of maintaining the authority of the central government and realizing centralized and unified leadership. Strengthening the four consciousnesses is the ideological basis and objective requirement of maintaining the central authority and realizing centralized and unified leadership. Therefore, party members and cadres should always keep in mind the lifeline of loyalty to the party, reinforcing their political stand, clarifying their political direction, sticking to political rules and abide by political discipline. Thirdly, it is significant to insist on the prohibition of orders and ensure the smooth implementation of government orders. Unblocked government decrees and prohibitions are the core requirements for upholding the authority of the CPC Central Committee and centralized and unified leadership. No party member must be duplicitous and disobedient on major decisions and major issues concerning the overall situation, such as the party's basic theory, ideological line, and policy guidelines. On the contrary, all party members must achieve "resolute response advocated by the CPC Central Committee, resolute compliance with the $\mathrm{CPC}$ Central Committee's decision, and resolute inaction prohibited by the CPC Central Committee."[1]Finally, we should establish a constitutional system to govern the Party according to regulations. The goodness of the system is the greatest goodness. Only by establishing the system can we provide the basic rules for governing the Party by regulating the Party. General Secretary Xi Jinping emphasized that rules and regulations are related to the life of the Party and must be strictly enforced, considering that the system cannot be made into a paper tiger or a scarecrow.[2]At present, "the whole party must strictly implement the reporting system for major issues"[3]. The system of asking for instructions and reporting is our Party's fine tradition and an effective operating mechanism of democratic centralism. When Party members and cadres are involved in major issues and make major decisions, they must report to the organization in accordance with the regulations and procedures. This is a political discipline, a political rule and a touchstone of party spirit.

\subsection{Strict discipline and rules of the party}

To strengthen the party's political construction, we must strictly abide by the party's political discipline and rules, and follow the party constitution as the fundamental basis. First, respect, abide by and safeguard the Party Constitution. Xi Jinping pointed out that "the party constitution is the fundamental law of the party and the general rule that the whole party must follow."[4]The Party Constitution is not only the general constitution and general rules of the Party, but also the fundamental principle that the whole Party must abide by. Although the Party has many disciplines, political discipline is the most fundamental, important and crucial discipline. If disciplinary rules are the "yardstick" for governing the party, then the Party Constitution is the "yardstick" for establishing rules and regulations. All party members must firmly cultivate the awareness of the party constitution, take the initiative to practice mind learning with the party constitution as the standard, and constantly improve their party spirit. In addition, it is necessary to consciously abide by and uphold the Party Constitution, act in accordance with the provisions of the Party Constitution, and always remind ourselves of "Do not forget your initiative mind and keep in mind the mission". Secondly, party members and cadres should strictly abide by political discipline and rules.Strict discipline and clear rewards and punishments are the fundamental guarantee for the Communist Party to maintain its purity and advancement for a long time. The key for the Party to manage the Party and strictly manage the Party in an allround way depends on political discipline and rules. When party members and cadres strictly abide by political discipline and political rules, they must ensure the scientific and serious nature of discipline and rules and maintain the authority of discipline and rules. Party members and cadres should consciously abide by discipline and rules, be awe-inspiring, hold a ruler, talk and behave in line with party members' status, and take the organizational principles as the bottom line. Party members and cadres should have the courage to fight against privileged thoughts and privileged phenomena, never arbitrarily take charge of politics and seek personal gains, and consciously obey organizational arrangements and take the initiative to accept discipline and rules. Finally, it is momentous to carefully sketch the warning line in thought and behavior. General Secretary $\mathrm{Xi}$ Jinping summarized the individual behaviors of ignoring political discipline and rules in the party as seven haves, and exhorted leading cadres to raise their awareness and abide by political discipline and rules with negative examples. Discipline and rules are high-voltage lines, and once they are electrocuted, they will pay a heavy price. Party members and cadres should understand rules and observe discipline, maintain political determination on big and wrong issues, maintain political principles in speech and behavior, highlight political essence in the struggle against bad behavior, constantly improve political ability, strengthen political responsibility, draw a warning line on ideological behavior, and ensure that they do not step on the line or cross the border. 


\section{STRENGTHEN THE CONSTRUCTION OF THE PARTY'S LONG-TERM RULING ABILITY}

\subsection{Strengthen the Eight Abilities of the Party in Power in the New Era}

Whether the ruling party can be in power for a long time is the fundamental and key. General Secretary Xi Jinping pointed out that some leading cadres do not have the ability to solve new problems under the new situation, and require leading cadres to enhance their ruling ability through study and practice. [5]The report of the 19th National Congress of the Communist Party of China summarized the abilities that the Party should possess for long-term governance in the new era as eight abilities. Strengthening the eight abilities of the party in power is an inevitable requirement of the new era and new journey, which is related to the success or failure of the development of the party and the country. First, we must enhance our learning ability. The situation of the world and the situation of the Party are changing rapidly. Risks and challenges emerge one after another. Party members and cadres can overcome the "skill panic" only by enhancing their learning ability, enhancing their learning autonomy, and consciously arming themselves with Xi Jinping's new era of socialism with Chinese characteristics and improving their governing ability.Second, we must enhance our political leadership skills, which are the most crucial ruling skills. The party's political leadership depends on the height of the party's overall planning, the thickness of its theoretical accomplishment, the breadth of its international vision and the span of its strategic layout. Party members and cadres should adhere to the scientific thinking method, plan the layout and draw a blueprint, so as to push forward the great cause continuously. Third, we should enhance the ability of reform and innovation, get out of the "comfort zone" and insist on learning by doing. To enhance the ability of reform and innovation, we must first stimulate the enthusiasm of party members and cadres for reform and innovation, encourage party members and cadres to make bold attempts and be brave in trial and error. Party and government organs at all levels should combine actual innovative working methods, comprehensively utilize big data and cloud computing, thus formulating more targeted policies on the basis of overall planning. Fourth, we must enhance our ability of scientific development. To lead the economic development, we should adhere to the new development concept, uphold the harmonious coexistence between man and nature, focus on solving the problem of insufficient development imbalance, and better meet the people's needs for a better life. Fifth, we should enhance our ability to govern according to law. Party members and cadres should consciously respect and obey the law and learn the usage of the law, so as to continuously enhance their ability to solve reform problems, plan development plans and maintain the overall situation of stability by using the rule of law. Sixth, we must enhance the working ability of the masses. Party members and cadres are supported by the people mainly by their personality charm, work ability and work style. Party members and cadres should start from the things that the masses care about, take the people's longing for a better life as their goal, and constantly innovate methods to be the guides of the masses.Seventh, we must enhance our ability to pay close attention to implementation. Paying close attention to the implementation is not only an important embodiment of the Party's ruling ability, but also an important yardstick of the Party members' cadres' working ability. Party members and cadres should come up with practical policies, do practical things and seek practical results, combine vigorous and resolute actions with long-term achievements, and push forward various tasks with the spirit of nailing nails. Eight, it is crucial to enhance the ability to control risks. To lead the people in the great struggle with many new historical characteristics, the Party must enhance the ability to control risks, improve the ability to overcome difficulties and control the overall situation, be brave in facing various situations and be good at handling various difficulties.

\subsection{Build a contingent of highly qualified and specialized cadres}

After the completion of the grand blueprint, cadres are the key factor. Building a contingent of high-quality professional cadres is a basic and leading project. It is also a long-term solution to strengthen the party's longterm ruling ability, advancement and purity.First of all, we must adhere to the principle that the party manages cadres, ensuring that the contingent of cadres is advanced, pure and responsible. Only by upholding the party's absolute leadership over the work of cadres can we consolidate the ruling foundation of the ruling party and ensure that party members and cadres are loyal to the party and always maintain their advanced nature and purity. In the appointment of cadres, we should insist on having both ability and political integrity, paying special attention to talents, selecting talents and talents, and promoting talents, so as to ensure that people with both ambitions and talents of latitude and longitude will be selected into the party's cadre ranks. Secondly, we must adhere to the correct orientation of selecting and employing people to ensure the political firmness of party members and cadres. The selection of cadres should highlight political standards, and take safeguarding the central authority, establishing the four consciousnesses, and implementing the party's principles and policies as important yardsticks, and promote and reuse those cadres who are responsible for party loyalty, dare to stand up, and be fair and decent. 
We should build a system in which leading cadres are able to rise and fall, promote cadres who can lean down, roll up their sleeves, and open their arms, and repel cadres who are officials who are dishonest, unscrupulous, and disorderly, so as to form a talentoriented, mediocrity-oriented, and enhance the combat effectiveness of cadres. Thirdly, we should attach great importance to reserve and select young cadres to ensure the successors of the party's cause. The report of the 19th National Congress requires that young cadres who have been tested by practice should be selected and used. The organizational department of the Party should reserve and select young cadres with grass-roots practical work experience from the perspective of the Party's long-term governance, and pay attention to cultivating their professional ability and professional spirit to meet the new requirements of the development of the new era. Finally, we should establish an incentive and fault-tolerant mechanism to ensure that party members and cadres can make great achievements. Incentive and fault-tolerant mechanism is a beneficial exploration for party members and cadres who care for and take responsibility, do practical things, and do not play favoritism, which highlights the orientation of selecting and employing people in the new era. Organizational departments should create a tolerant atmosphere, build incentive mechanism and faulttolerant and error-correcting mechanism, and give party members and cadres a reassurance. It should be pointed out that the incentive and fault-tolerant mechanism is neither a panacea, nor a amulet for party members and cadres to be incompetent and unclean. We should resolutely put an end to the fact that the original intention of the party organization to protect and motivate cadres is to protect and condone cadres.

\section{MOBILIZE THE ENTHUSIASM, INITIATIVE AND CREATIVITY OF THE WHOLE PARTY}

\subsection{Fully carry forward the democracy within the party}

Inner-party democracy is both the life of the party and an important part of inner-party political life. Carrying forward inner-party democracy is a key link in party building. Only by fully carrying forward innerparty democracy, listening to the voices of party members and understanding the demands of party members can we truly mobilize the enthusiasm, initiative and creativity of party members and cadres, and ensure that the party's policies are truly implemented. On the one hand, it is vital to respect the dominant position of party members and guarantee their democratic rights. Party members are the cells of the party's body. Only when the democratic rights of each party member are guaranteed can inner-party democracy be fully promoted. Party organizations at all levels should earnestly implement the rights granted to party members by the party constitution, which is of great significance for enhancing party members' sense of responsibility and giving full play to their vanguard role. Party organizations at all levels should unblock the channels for party members to participate in inner-party affairs, create a clean and positive political environment, encourage party members to say everything they know, and take measures to effectively protect comrades who dare to tell the truth. On the other hand, we should improve the inner-party democratic system. To perfect the inner-party democratic system, we should take safeguarding the democratic rights of party members and enhancing the cohesion, creativity and combat effectiveness of party organizations as the starting point and the foothold. To ameliorate the inner-party election system, we must adhere to the party's absolute leadership over the election work, enhancing the way of producing candidates by combining democratic recommendation with organizational nomination, and comprehensively introducing the candidates' situation, so that the party representatives can have a comprehensive understanding of the candidates' performance, ability and political morality. Perfecting the Party's congress system, the Party congress and congress system is an effective way to realize intraParty democracy[6], earnestly implement the tenure system and proposal system of party representatives, and further improve the systems of party representatives participating in major decisions, recommending and appraising cadres, and keeping close contact with the masses.

\subsection{Sincerely help party members and cadres grow up}

General Secretary Xi Jinping pointed out that Party cadres are the leaders in promoting the great cause. Although the overall quality of Party cadres has been continuously enhanced, which can basically meet the needs of modernization construction, there are also outstanding problems such as not serving as an official.[7]To completely reverse the situation that party members and cadres can't do it, don't want to do it, and dare not do it, party organizations at all levels must focus on improving the comprehensive quality of party members and cadres and creating a good and relaxed growth environment for cadres. On the one hand, it is wise to strengthen the training of party members and cadres. The phenomenon that party members and cadres can't do anything is often due to their lack of ability. Therefore, training should aim at the knowledge gap, lack of ability and method of party members and cadres, and accurately promote the training of policy theory, method skills, laws and regulations, etc. In view of weaknesses, we should make up for gaps, eliminate confusion and doubts of party members and cadres, 
enhance their sense of subject and mission, and focus on solving the problem of insufficient ability in the new era. On the other hand, we should strictly manage and care for party members and cadres, because strict management and enthusiastic care are the twin engines to help party members and cadres grow up healthily. Strict management means strengthening the restraint on party members and cadres, supervising their words and deeds, not conniving or sheltering them, and criticizing and educating and dealing with violations of discipline and discipline, while care means actively responding to the needs and demands of party members and cadres, paying attention to their mental health and ideological trends, and solving practical difficulties in their work and life. The value orientation of strict management and care is to help party members and cadres grow. Strict management can avoid fewer mistakes and detours, and enthusiastic care can stimulate the enthusiasm and positive motivation of party members and cadres.

\section{CONCLUSION}

Socialism with Chinese characteristics has entered a new era.[8] In the new era, we should take the party's political construction as the guidance: firmly adhere to the "two maintenance" and strictly understand the party's discipline and rules; constantly strengthen the construction of the party's long-term governance ability; strengthen the party's "eight skills" in governance in the new era; build a high-quality professional cadre team; mobilize the enthusiasm and creativity of the party: give full play to democracy within the party and help Party members and cadres grow up with sincerity. Only in this way can the party be built into a Marxist ruling party that always walks in the forefront of the times, be supported by the people wholeheartedly, have the courage to self-revolution, withstand the test of all kinds of storms, and be full of vigor and vitality.

\section{ACKNOWLEDGMENTS}

This paper is a periodical achievement of fund whose name is Historical experience and Contemporary Enlightenment of safeguarding the authority of the Party Central Committee and centralized and unified leadership in Yan'an Period.

\section{REFERENCES}

[1] Li Zhanshu. Resolutely safeguard the authority of the CPC Central Committee [N]. People's Daily, 2016-11-15(006).

[2] Strengthen the Innovation of Anti-Corruption System and Mechanism and Institutional Guarantee, and Further Promote the Building of a Clean and Honest Government and the Anti-
Corruption Struggle [N]. People's Daily,2014-115(001).

[3] Some Guidelines on Political Life within the Party under the New Situation [N]. People's Daily,201611-3(005).

[4] Xi Jinping. Seriously study the Party Constitution and strictly abide by the Party Constitution [N]. People's Daily,2012-11-20(001).

[5] Xi Jinping on Governance [M]. Beijing: Foreign Languages Press,2014:407.

[6] Selected Works of Mao Zedong (Vol.5) [M]. Beijing: People's Publishing House, 1999:137.

[7] Xi Jinping. Speech at the Seminar on Studying and Implementing the Spirit of the Fifth Plenary Session of the Eighteenth Central Committee of the Communist Party of China by Leading Cadres at the Provincial and Ministerial Levels [N]. People's Daily,2016-5-10(002).

[8] Xi Jinping. Building a moderately prosperous society in an all-round way and winning the great victory of socialism with Chinese characteristics in the new era: Report on the 19th National Congress of the Communist Party of China. 